\title{
The Role of Cell Cycle Regulatory Protein, Cyclin D1, in the Progression of Thyroid Cancer
}

\author{
Songtao Wang, M.D., Ph.D., Ricardo V. Lloyd, M.D., Ph.D., Michael J. Hutzler, M.D., \\ Marjorie S. Safran, M.D., Nilima A. Patwardhan, M.D., Ashraf Khan, M.D. \\ Departments of Pathology (SW, MJH, AK), Medicine (MSS) and Surgery (NAP), University of Massachusetts \\ Memorial Medical Center, University Campus, Worcester, Massachusetts and Department of Laboratory \\ Medicine and Pathology, Mayo Clinic, Rochester, Minnesota (RVL)
}

Cell cycle progression is facilitated by cyclindependent kinases that are activated by cyclins including cyclin D1 and inactivated by cyclindependent kinase inhibitors (CDKIs) such as p27. Our previous studies have demonstrated decreased p27 expression in both papillary and more aggressive carcinomas of the thyroid compared to thyroid adenoma and almost similar level of cyclin D1 expression between thyroid adenoma and papillary carcinoma. These results indicate that CDKIs may have an important role in the carcinogenesis of the thyroid and that they probably have a limited role in malignant progression of the thyroid cancer. The role of cyclin D1 in malignant progression of thyroid carcinoma has yet to be established. We studied the expression of cyclin D1 by immunohistochemistry in 34 cases of conventional papillary carcinoma (CPC), 10 cases of minimally invasive follicular carcinoma (MIFC), and 32 cases of more aggressive thyroid carcinoma (ATC), which included 11 tall cell variants, one columnar cell variant of papillary carcinoma, seven insular carcinomas, and 13 anaplastic carcinomas. Cyclin D1 staining was classified by staining score as 0 , negative; $1+$, less than 25\%; $2+, 25$ to $50 \%$; and $3+$, more than $50 \%$ tumor cells staining positive. Kruskal-Wallis oneway ANOVA and Wilcoxon Rank Sum/MannWhitney $U$ Test was used to assess the difference in the expression of cyclin D1 between the study groups. Twenty-eight out of the $34 \mathrm{CPCs}$ were cyclin D1 positive, $24(70 \%)$ were $1+, 3(9 \%)$ were $2+$, and one (3\%) were $3+$ positive. Seven of 10 MIFCs were cyclin D1 positive, five $(71 \%)$ were $1+$, and the remaining two $(29 \%)$ were $2+$ positive. On the other

Copyright () 2000 by The United States and Canadian Academy of Pathology, Inc.

VOL. 13, NO. 8, P. 882, 2000 Printed in the U.S.A.

Date of acceptance: February 11, 2000.

Address reprint requests to: Ashraf Khan, M.D., Department of Pathology, UMass Memorial Medical Center, University Campus, 55 Lake Avenue North, Worcester, MA 01655; e-mail: ashraf.khan@banyan.ummed.edu; fax: 508-856-2968. hand, 28 of 32 ATCs showed cyclin D1 immunostaining. Of these, three $(9 \%)$ were $1+$, five $(13 \%)$ were $2+$, and $20(63 \%)$ were $3+$ positive. This study demonstrates a significant overexpression of cyclin D1 in ATC compared CPC $(P<.001)$ and MIFC $(P<$ .005), suggesting that the cyclin D1 expression may play a role in tumor progression and may have prognostic significance in thyroid cancer.

KEY WORDS: Anaplastic carcinoma, Columnar cell variant, Cyclin D1, Insular carcinoma, Minimally invasive follicular carcinoma, Papillary carcinoma, Tall cell variant.

Mod Pathol 2000;13(8):882-887

The loss of regulatory control of the cell cycle, leading to unrestrained cell proliferation, is a hallmark of cancer. Cyclins, the regulatory subunits of cyclindependent kinases (CDKs), control the passage of proliferating cells through key checkpoints in the cell cycle (1-3, for review). The deregulation of cyclin expression results in the loss of control of normal growth. The linkage between oncogenesis and cyclins was made with the discovery of two cyclins in tumors. Cyclin A gene was found to be the integration site of a fragment of the hepatitis B virus genome in hepatocellular carcinoma (4). In parathyroid adenomas, the PRAD1 (cyclin D) gene is overexpressed as a result of a pericentrimeric inversion of chromosome 14, which places the PRAD1 gene under control of the parathyroid hormone promoter gene (5-7). PRAD1 is also activated by $\mathrm{t}(11,14)$ translocation in mantle cell lymphoma due to the placement of cyclin D1 gene next to an immunoglobulin heavy chain enhancer gene (8). Overexpression of the cyclin D1 gene has been shown in some breast carcinomas, hepatocellular carcinomas, esophageal carcinomas, head and neck squamous cell carcinomas, and thyroid carcinomas (9-19). Other cyclins have also been implicated in tumorigenesis. Cyclin D2 and E are overexpressed in colorectal carcinomas (20). Cyclin E 
has been found to be overexpressed in breast carcinomas and may be associated with more advanced stages of breast cancer (21). The overexpression of positive growth regulators may overwhelm the arrest mechanism of the normal cell cycle and lead to uncontrolled cell proliferation (1).

However, the overexpression of positive growth regulators may not be the only mechanism by which cell proliferation is stimulated. Alternatively, the underexpression of negative growth regulators, such as the cyclin-dependent kinase inhibitors (CDKIs), can have the same effect on the cell cycle. p27 negatively controls the cell transition from quiescence to proliferation by inhibiting the cyclinCDK complexes (1). Our previous studies have demonstrated a decreased p27 expression in both papillary and more aggressive carcinomas of the thyroid compared to their benign counterparts (2224). We also demonstrated a similar level of cyclin D1 expression in papillary carcinoma and follicular adenoma (24). The results of these studies indicate that cyclin-dependent kinase inhibitors may have a more important role than cyclins in thyroid carcinogenesis and that they probably play a limited role in the malignant progression of thyroid cancer. Although some studies (16-17) have shown cyclin D1 overexpression in thyroid carcinoma compared to benign lesions, its role in the malignant progression of thyroid cancer is yet to be established. We hypothesize that although the underexpression of $\mathrm{p} 27$ is important for the malignant transformation of the thyroid, the overexpression of cyclins, such as cyclin D1, may lead to progression and dedifferentiation of thyroid carcinoma. The aim of this study is to determine if differences in cyclin D1 immunostaining can aid in the differentiation of indolent from more aggressive thyroid carcinomas (ATCs). Furthermore, such immunostaining may suggest possible mechanisms for thyroid malignant progression.

\section{MATERIALS AND METHODS}

\section{Tissue Specimens Studied}

Thirty-four cases of conventional papillary carcinoma (CPC), 10 cases of minimally invasive (encapsulated) follicular carcinoma, and 32 cases of more aggressive carcinoma of the thyroid (including 11 tall cell variants and one columnar cell variant of papillary carcinoma, seven insular carcinomas, and 13 anaplastic carcinomas) were selected from the surgical pathology files of UMass Memorial (University campus) Medical Center, Worcester, Massachusetts (diagnosed between 1992 and 1997), and Mayo Clinic, Rochester, Minnesota (diagnosed between 1960 and 1993). All the cases were reviewed by at least two pathologists to confirm the diag- noses. The diagnosis of CPC, MIFC, and more aggressive carcinoma was based on established histologic criteria (25). All 10 MIFCs were encapsulated tumors with nine showing focal transcapsular invasion and one showing a focus of vascular invasion. Paraffin blocks were selected for immunohistochemistry to include both the tumor and the rim of normal thyroid tissue around it, the latter to serve as a control. Normal thyroid tissue was seen in all 76 cases.

\section{Immunohistochemistry}

All thyroid resection specimens in this study were fixed in $10 \%$ buffered formalin and paraffin embedded by routinely processing through a VIP Tissue Tek processor (Miles Scientific, Naperville, IL). Sections were cut at a thickness of $4 \mu \mathrm{m}$, heated at $60^{\circ} \mathrm{C}$ for $30 \mathrm{~min}$, then deparaffinized and hydrated through a series of xylene and alcohol baths before staining. The slides were microwaved with a proprietary antigen retrieval solution (citrate buffer) (BioTek Solutions, Santa Barbara, CA) for $5 \mathrm{~min}$ in an 800 watt microwave oven. After replenishment of this solution, the slides were microwaved again for an additional $5 \mathrm{~min}$ and then allowed to cool for $20 \mathrm{~min}$. Immunohistochemical staining was performed with monoclonal anti-cyclin D1 antibody (Novocastra/Vector, Burlingame, CA), at dilution of $1: 20$, using a standard avidin/biotin complex (ABC) method as implemented on a Techmate 1000 (BioTek) automated immunostainer. The staining procedure consisted of a 45-min incubation in the primary antibody, followed by brief buffer washes, and then incubation in a cocktail of biotinylated anti-mouse IgG/IgM (BioTek) for $30 \mathrm{~min}$. The slides were then washed, incubated in avidin/biotin complex (BioTek) for $30 \mathrm{~min}$, washed, and then reacted with diaminobenzidine and hydrogen peroxide to visualize the end product. The sections were counterstained with hematoxylin. A breast cancer known to express cyclin D1 served as positive control for cyclin D1. For negative control, nonimmune serum was substituted for primary antibody.

\section{Evaluation of Immunostaining}

Immunostained sections were evaluated by estimating the percentage of tumor cells stained with monoclonal anti-cyclin D1 antibody without knowledge of the pathological diagnosis. Only a distinct brown nuclear staining of tumor cells was considered as positive. The nuclear staining in the normal thyroid tissue surrounding the tumor was used as an internal negative control for cyclin D1. The sections were examined on a Olympus microscope using an eyepiece graticule (Olympus, Tokyo, Japan) to facilitate cell counting. The sections were 
examined first under low magnification $(50 \times$ and $100 \times)$ to see the overall staining pattern and later at a higher magnification $(400 \times)$, at which a minimum of 1000 cells were counted using the eyepiece graticule. The percentage of positive cells was then calculated and positive staining scored as: $1+=$ less than $10 \%, 2+=11$ to $50 \%$ and $3+=$ more than $50 \%$ tumor cells stained positive.

\section{Data Analysis}

In order to establish a difference in cyclin D1 expression among MIFC, CPC, and the more ATCs, Kruskal-Wallis one-way ANOVA was used. Following determination of significance, pair-wise comparisons were performed using the Wilcoxon Rank Sum/Mann-Whitney U Test (26). Statistical significance was defined at the level of $P<.05$ (twotailed), divided evenly among multiple comparisons.

\section{RESULTS}

The normal thyroid tissue in all 76 cases was negative for cyclin D1. The number of cases positive for cyclin D1 along with the score of nuclear staining is summarized in Table 1. Twenty-eight out of 34 CPCs were cyclin D1 positive, $24(70 \%)$ were $1+$ (Fig. 1A), 3 (9\%) were $2+$, and one (3\%) was $3+$ positive. Of the 10 minimally MIFCs, seven were cyclin D1 positive. Of these, five (71\%) were $1+$, and the remaining two $(29 \%)$ were $2+$ positive. On the other hand, 28 out of 32 more ATCs showed cyclin D1 immunostaining. Of these, three $(9 \%)$ were $1+$, five (13\%) were $2+$, and $20(63 \%)$ were $3+$ positive. The degree of cyclin D1 expression was significantly higher in histologically more aggressive carcinomas compared to both conventional papillary thyroid carcinomas $(P<.001)$ and MIFCs $(P<.005)$. There was no significant difference in cyclin D1 expression between MIFCs and CPCs $(P=.8)$. Tall cell/ columnar cell variants of papillary carcinoma

TABLE 1. Expression of Cyclin D1 in Indolent and More Aggressive Thyroid Carcinomas

\begin{tabular}{lrrrrr}
\hline \multirow{2}{*}{\multicolumn{1}{c}{ Diagnosis }} & \multicolumn{5}{c}{ Staining Score } \\
\cline { 2 - 6 } & $n$ & 0 & 1 & 2 & 3 \\
\hline Conventional PC & 34 & 6 & 24 & 3 & 1 \\
Minimally invasive FC & 10 & 3 & 5 & 2 & 0 \\
TCV/CCV of PC & 12 & 1 & 1 & 2 & 8 \\
Insular carcinoma & 7 & 0 & 1 & 2 & 4 \\
Anaplastic carcinoma & 13 & 3 & 1 & 1 & 8 \\
\hline
\end{tabular}

PC, Papillary carcinoma; FC, Follicular carcinoma; TCV, Tall cell variant; CCV, Columnar cell variant.

$P<.001$, which assessed the difference of cyclin D1 expression between conventional PC and more aggressive (TCV/CCV PC, insular and anaplastic) carcinomas of the thyroid.

$P<.005$, which assessed the difference of cyclin D1 expression between minimally invasive FC and more aggressive (TCV/CCV PC, insular and anaplastic) carcinomas of the thyroid.
(TCV/CCV) showed 3+ expression of cyclin D1 in 8 of $12(66 \%)$ cases (Fig. 1B) and the remaining four cases showed $2+, 1+$ positive, and negative expression of cyclin D1 in 2, 1 , and 1 case, respectively. Insular carcinoma demonstrated $3+$ expression of cyclin D1 in four of seven (57\%) cases (Fig. 1C), the remaining three cases showed $2+$ staining in 2 , and $1+$ staining in one case. Anaplastic carcinoma demonstrated $3+$ cyclin D1 staining in 8 of $13(62 \%)$ cases (Fig. 1D), one case each was $2+$ and $1+$ positive, and the remaining three cases were cyclin D1 negative. It was interesting to note that the giant cell nuclei of anaplastic carcinoma, giant cell type, demonstrated stronger cyclin D1 staining compared to the nuclei of the surrounding mononuclear tumor cells, indicating that the overexpression of cyclin D1 may be related to the formation of the tumor giant cells in anaplastic carcinoma.

\section{DISCUSSION}

Malignant transformation as a result of uncontrolled cell proliferation may result from the deregulation of cyclins and/or CDKIs. Increased expression of the cell cycle up-regulators such as cyclins or reduced expression of the cell cycle downregulators such as CDKIs may contribute to tumor formation (1-3). Our previous studies have suggested that reduced expression of $\mathrm{p} 27$, plays a more important role than cyclin D1 in thyroid carcinogenesis; however, p27 may have a limited role in malignant progression of thyroid cancer (22-24). To determine whether cyclin D1 overexpression was involved in thyroid malignant progression, we examined 34 cases of CPC of the thyroid, 10 cases of MIFC, and 32 cases of more aggressive carcinomas of the thyroid using immunohistochemistry. Our study demonstrates a significant overexpression of cyclin D1 in more aggressive carcinomas compared to the CPC and the minimally invasive (encapsulated) follicular carcinoma of the thyroid, suggesting that the cyclin D1 expression may play a role in tumor progression and may have prognostic significance.

The CPC and minimally invasive (encapsulated) follicular carcinoma are both well-differentiated thyroid carcinoma with indolent behavior and excellent prognosis (25). Tall cell and columnar cell variants of papillary carcinoma tend to occur in older patients and are often larger tumors with an increased incidence of vascular invasion and frequent extrathyroidal extension $(27,28)$. Insular carcinoma is a poorly differentiated carcinoma with an intermediate morphology and clinical behavior between the differentiated (papillary) carcinoma of the thyroid and anaplastic carcinoma $(29,30)$. Anaplastic (undifferentiated) carcinoma of the thyroid 

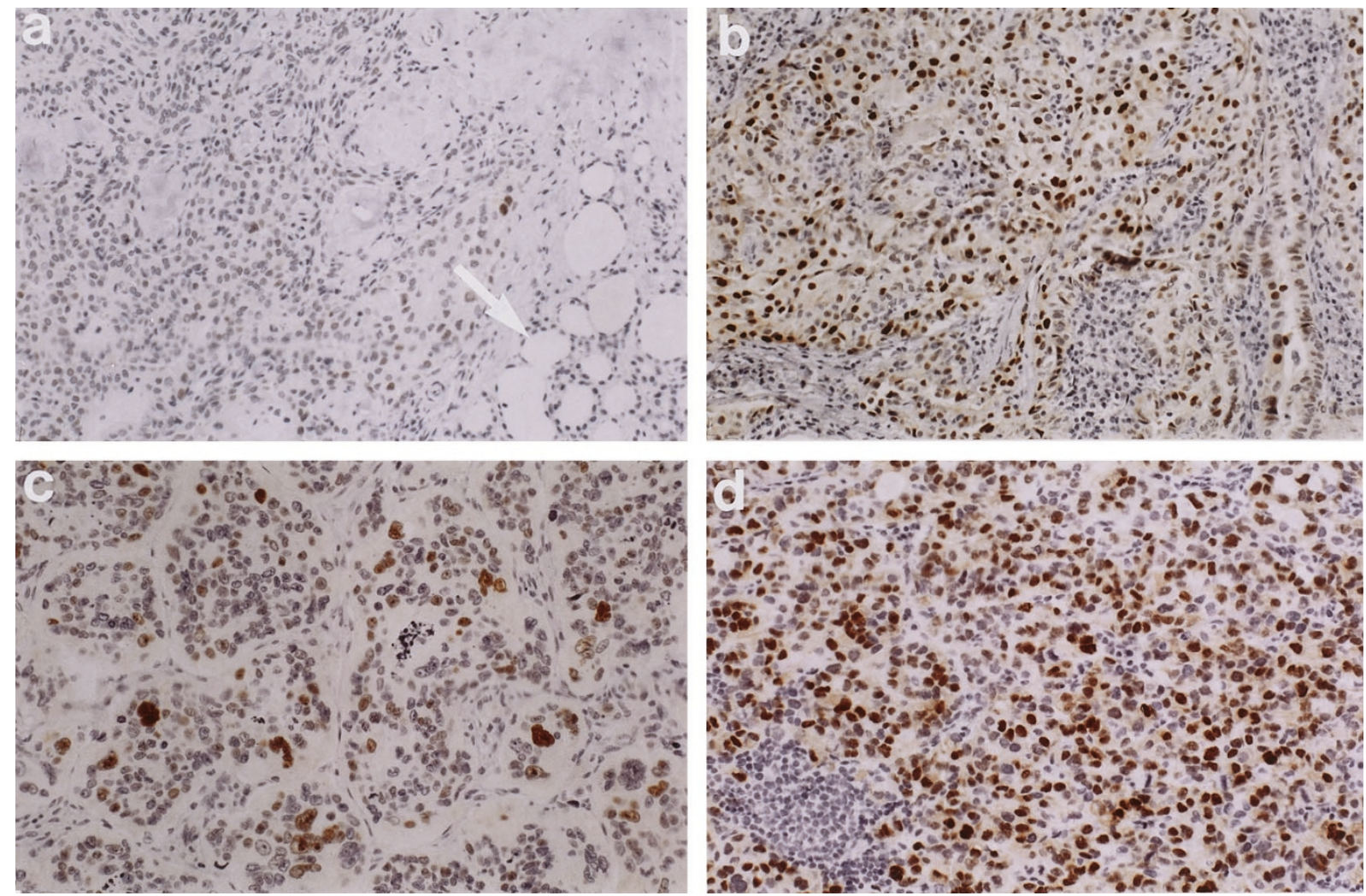

FIGURE 1. Cyclin D1 immunostaining showing $1+$ staining in conventional papillary carcinoma (A), $3+$ staining each in tall cell variant of papillary carcinoma (B), insular carcinoma (C), and anaplastic carcinoma of the thyroid (D). The residual normal thyroid (arrow) and stromal lymphocytes (D) are cyclin D1 negative (immunoperoxidase stain, original magnification, $200 \times$ ).

often presents with fast-growing neck mass and is a highly malignant tumor. Most ATCs including insular and anaplastic carcinoma are thought to have arisen from a preexisting, well-differentiated papillary or follicular carcinoma (25). Several oncogenes or tumor suppressor genes have been shown to contribute to the malignant progression and dedifferentiation of thyroid cancer (31-35). The expression of bcl-2 has been observed in differentiated and poorly differentiated thyroid carcinoma and to a lesser degree in anaplastic carcinoma (31, 32); p53 expression on the other hand is seen more often in poorly differentiated and anaplastic carcinoma compared to differentiated thyroid carcinoma (33-35). Mutation of the p53 gene has been found in a high percentage of anaplastic carcinomas. This mutation is not present in the residual differentiated papillary carcinoma component suggesting that p53 mutation occurred after the development of the papillary carcinoma and plays a key role in the malignant progression of the tumor (3335). The overexpression of cyclin D1 may contribute to cell proliferation and to subsequent mutations of the tumor suppressor gene, p53, by facilitating the quiescent cells entering to and passing through the cell cycle.

Cyclin D1 forms a multimer complex with cyclindependent kinase (CDK), which facilitate transition through the restriction point of cell cycle by inactivation of the retinoblastoma tumor-suppresser protein $(\mathrm{pRb})$ as a result of its hyperphosphorylation by CDK. Hyperphosphorylation of $\mathrm{pRb}$ leads to the release of E2F transcription factors and other proteins from their complexes with $\mathrm{pRb}$, which activates genes coding for positive regulators of cell proliferation (1-3). Constitutive overexpression of cyclin D1 caused by chromosomal abnormalities is seen in neoplasms involving parathyroid gland, lymph node, and liver (4-8). However, in a subset of breast carcinoma cyclin D1 protein overexpression has been seen in the absence of amplification of the cyclin D1 gene, suggesting that gene amplification is not the only mechanism that results in increased protein expression (36). Overexpression of cyclins may also be due to increased RNA/protein stability, and due to the increased sensitivity of tumor cell to external stimulating signals such as hormones $(37,38)$.

Our recent studies indicate a positive correlation between the expression of eukaryotic translation initiation factors $4 \mathrm{E}$ and $2 \alpha$ (eIF-4E and eIF- $2 \alpha$ ) in thyroid cancer progression (39). We and others have found earlier that overexpression of eIF-4E causes increased expression of cyclin D1 in NIH T3 cells and in colonic neoplasms (40-42). Increased expression of eukaryotic translation initiation fac- 
tors eIF-4E and eIF- $2 \alpha$ induced by $c$ - $m y c$ and other oncogenes has been described previously $(43,44)$. Further studies are needed to determine the oncogenes that cause an increase in cyclin D1 expression through the translation initiation pathway in more aggressive carcinomas of the thyroid.

In summary, there is a significant overexpression of cyclin D1 in more ATCs compared to the CPC and MIFC of the thyroid, suggesting that cyclin D1 expression may play a role in tumor progression and may have prognostic significance.

\section{REFERENCES}

1. Dirks PB, Rutka JT. Current concepts in neuro-oncology: the cell cycle - a review. Neurosurgery 1997;40:1000-15.

2. Sherr CJ, Roberts JM. Inhibitors of mammalian G1 cyclindependent kinases. Genes Dev 1995;9:1149-63.

3. Hall M, Peters G. Genetic alterations of cyclins, cyclindependent kinases, and cdk inhibitors in human cancers. Adv Cancer Res 1996;68:67-108.

4. Wang J, Chenivesse X, Henglein B, Brechot C. Hepatitis B virus integration in a cyclin A gene in a hepatocellular carcinoma. Nature 1990;343:555-7.

5. Quelle DE, Ashmun RA, Shurtleff SA, Kato JY, Bar-Sagi D, Roussel MF, et al. Overexpression of mouse D-type cyclins accelerates G1 phases in rodent fibroblasts. Genes Dev 1993; 7:1559-71.

6. Motokura T, Bloom T, Kim HG, Juppner H, Ruderman JV, Kronenberg HM, et al. A novel cyclin encoded by a bcl-1 linked candidate gene. Nature 1991;350:512-5.

7. Matsushime H, Roussel MF, Ashmun RA, Sherr CJ. Colonystimulating factor-1 regulates cyclins during the G1 phase of cell cycle. Cell 1991;65:701-13.

8. Withers DA, Harvey RC, Faust JB, Melnyk O, Carey K, Meeker TC. Characterization of a candidate bcl-1 gene. Mol Cell Biol 1991;11:4846-53.

9. Bartkova J, Lukas J, Strauss M, Bartek J. Cyclin D1 oncoprotein accumulates in malignancies of diverse histogenesis. Oncogene 1993;10:775-8.

10. Buckley MF, Sweeney KJ, Hamilton JA, Sini RL, Manning DL, Nicholson RI, et al. Expression and amplification of cyclin genes in human breast cancer. Oncogene 1993;8:2127-33.

11. Jares P, Fernandez PL, Campo E, Nadal A, Bosch F, Aiza G, et al. PRAD1/cyclin D1 gene amplification correlates with mRNA overexpression and tumor progression in human laryngeal carcinomas. Cancer Res 1994;54:4813-7.

12. Jiang W, Kahn SM, Tomita N, Zhang YJ, Lu SH, Weinstein IB. Amplification and expression of human cyclin D gene in esophageal cancer. Cancer Res 1992;52:2980-3.

13. Lukas J, Muller H, Bartkova J, Spitkovsky D, Kjerulff A, Jansen-Durr P, et al. DNA tumor virus oncoproteins and retinoblastoma gene mutations share the ability to relieve the cell's requirement of cyclin D1 function in G1. J Cell Biol 1994;125:625-38.

14. Michalides R, van Veelen N, Hart A, Loftus B, Wientjens E, Balm A. Overexpression of cyclin D1 correlates with recurrence in a group of forty-seven operable squamous cell carcinomas of the head and neck. Cancer Res 1995;55:975-8.

15. Moran E. DNA tumor virus transforming proteins and the cell cycle. Curr Opin Genet Dev 1993;3:63-70.

16. Zou M, Shi Y, Farid NR, Al-Sedairy ST. Inverse association between cyclin D1 overexpression and retinoblastoma gene mutation in thyroid carcinomas. Endocrine 1998;8:61-4.

17. Lazzereschi D, Sambuco L, Carnovale Scalzo C, Ranieri AR, Mincione G, Nardi F, et al. Cyclin D1 and cyclin E expression in malignant thyroid cells and in human thyroid carcinoma. Int J Cancer 1998;76:806-11.

18. Muro-Cacho CA, Holt T, Klotch D, Mora L, Livingston S, Futran N. Cyclin D1 expression as a prognostic parameter in papillary carcinoma of the thyroid. Otolaryngol Head Neck Surg 1999;120:200-7.

19. Erickson LA, Jin L, Goellner JR, Lohse C, Pankratz BSV, Zukerberg LR, et al. Pathologic features, proliferative activity and cyclin D1 expression in Hurthle cell neoplasms of the thyroid. Mod Pathol 2000;13:186-92.

20. Leach FS, Elledge SJ, Sherr CJ, Willson JK, Markowitz S, Kinzler KW, et al. Amplification of cyclin genes in colorectal carcinoma. Cancer Res 1993;53:1986-9.

21. Keyomarsi K, O'Leary N, Molnar G, Lees E, Fingert HJ, Pardee AB. Cyclin E, a potential prognostic marker for breast cancer. Cancer Res 1994;54:380-5.

22. Lloyd RV, Jin L, Qian X, Kulig E. Aberrant expression of p27 ${ }^{\text {kipl }}$ in endocrine and other tumors. Am J Pathol 1997; 150:401-7.

23. Erickson LA, Jin L, Wollan PC, Thompson GB, van Heerden J, Lloyd RV. Expression of p27 $7^{\mathrm{kip} 1}$ and Ki-67 in benign and malignant thyroid tumors. Mod Pathol 1998;11:169-74.

24. Wang S, Wuu J, Savas L, Patwardhan N, Khan A. The role of cell cycle regulatory protein, cyclin D1, cyclin E and p27 in thyroid carcinogenesis. Hum Pathol 1998;29:1304-9.

25. Rosai J, Carcangiu ML, DeLellis RA. Tumors of the thyroid gland. In: Rosai, J. Sobin L, editors. Atlas of tumor pathology. 3rd Series. Fasc. 5. Washington, DC: Armed Forces Institute of Pathology; 1992.

26. Armitage P, Berry G. Statistical methods in medical research. 3rd ed. Oxford: Blackball Science Ltd; 1994.

27. Johnson TL, Lloyd RV, Thomson NW, Beierwaltes WH, Sisson JC. Prognostic implications of the tall cell variant of papillary thyroid carcinoma. Am J Surg Pathol 1988;12:22-7.

28. Akslen LA, Varhaug JE. Thyroid carcinoma with mixed tallcell and columnar cell features. Am J Clin Pathol 1990;94: 442-5.

29. Carcangiu ML, Zampi G, Rosai J. Poorly differentiated ("insular") thyroid carcinoma. A reinterpretation of Langhans' "wuchernde Struma." Am J Surg Pathol 1984;8:655-68.

30. Aldinger KA, Samaan NA, Ibanez M, Hills CS Jr. Anaplastic carcinoma of the thyroid. A review of 84 cases of spindle and giant cell carcinoma of the thyroid. Cancer 1978;41:2267-75.

31. Pilotti S, Collini P, Rilke F, Cattoretti G, Del Bo R, Pierotti MA. BCL-2 protein expression in carcinomas originating from the follicular epithelium of the thyroid gland. J Pathol 1994;172: 337-42.

32. Pilotti S, Collini P, Del Bo R, Cattoretti G, Pierotti MA, Rilke F. A novel panel of antibodies that segregates immunocytochemically poorly differentiated carcinoma from undifferentiated carcinoma of the thyroid gland. Am J Surg Pathol 1994;18:1054-64.

33. Fagin JA, Matsuo K, Karmakar A, Chen DL, Tang SH, Koeffler HP. High prevalence of mutation of the p53 gene in poorly differentiated human thyroid carcinomas. J Clin Invest 1993; 91:179-84.

34. Ito T, Seyama T, Mizuno T, Tsuyama N, Hayashi Y, Dohi K, et al. Unique association of p53 mutations with undifferentiated but not with differentiated carcinomas of the thyroid gland. Cancer Res 1992;52:1369-71.

35. Nakamura T, Yana I, Kobayashi T, Shin E, Karakawa K, Fujita S, et al. p53 gene mutations associated with anaplastic transformation of human thyroid carcinomas Jpn J Cancer Res 1992;83:1293-8.

36. Zhang SY, Caamano J, Cooper F, Guo X, Klein-Szanto AJ. Immunohistochemistry of cyclin D1 in human breast cancer. Am J Clin Pathol 1994;102:695-8.

37. Musgrove EA, Hamilton JA, Lee CS, Sweeney KJ, Watts CK, Sutherland RL. Growth factor, steroid and steroid antagonist 
regulation of cyclin gene expression associated with changes in T-47D human breast cancer cell cycle progression. Mol Cell Biol 1993;13:3577-87.

38. Zukerberg LR, Yang WI, Gadd M, Thor AD, Koerner FC, Schmidt EV, et al. Cyclin D1 (PRAD1) protein expression in breast cancer: approximately one-third of infiltrating mammary carcinomas show overexpression of the cyclin D1 oncogene. Mod Pathol 1995;8:560-7.

39. Wang S, Lloyd RV, Hutzler MJ, Rosenwald IB, Patwardhan N, Savas L, et al. Expression of eukaryotic initiation factors $4 \mathrm{E}$ and $2 \alpha$ in thyroid carcinoma [abstract]. Lab Invest 1999;79: $70 \mathrm{~A}$.

40. Rosenwald IB, Lazaris-Karatzas A, Sonenberg N, Schmidt EV. Elevated levels of cyclin Dl in response to increased expression of eukaryotic initiation factor 4E. Mol Cell Biol 1993;13: 7358-63.
41. Rosenwald IB, Kaspar R, Rousseau D, Gehrke L, LeBoulch P, Chen JJ, et al. Eukaryotic translation initiation factor $4 \mathrm{E}$ regulates expression of cyclin $\mathrm{Dl}$ at transcriptional and posttranscriptional levels. J Biol Chem 1995;270:21176-80.

42. Rosenwald IB, Chen JJ, Wang S, Savas L, London IM, Pullman J. Upregulation of protein synthesis initiation factor eIF-4E is an early event during colon carcinogenesis. Oncogene 1999;18:2507-17.

43. Rosenwald IB, Rhoads DB, Callanan L, Isselbacher KJ, Schmidt EV. Increased expression of eukaryotic translation initiation factors eIF-4E and eIF- $2 \alpha$ in response to growth induction by $c$-myc. Proc Natl Acad Sci U S A 1993; 90:6175-8.

44. Rosenwald IB. Deregulation of protein synthesis as a mechanism of neoplastic transformation. Bioessays 1996;18:24350 .

\section{Book Review}

\section{McKenzie JC, Klein RM: Basic Concepts in Cell Biology and Histology: A Student's Sur- vival Guide, 427 pp, New York, McGraw- Hill, 2000 (\$29.50).}

Basic Concepts in Cell Biology and Histology: A Student's Survival Guide provides a review of information typically presented in the first year of medical school. Part I of this book covers cell biology and biochemistry (e.g., intracellular signaling). Part II presents an overview of basic histology and tissue function. The authors are respected medical educators, who clearly understand the material and the needs of medical students. They have succeeded in organizing and integrating a tremendous amount of information that is traditionally taught in separate courses (biochemistry, cell biology, immunology, histology, and physiology). The text is well-written, organized, succinct, easy to read, and up-to-date. Complex concepts are presented in a style that makes learning fun. Each chapter contains major topics and short discussions. Key facts and vocabulary are conveniently displayed in boxes. This is very helpful, because if the reader knows this key point, he/she can skip the discussion and move on to the next topic. The text is supplemented with beautiful continuous tone graphics and black and white line drawings. Clinical correlations are provided to link basic science material to applications in medicine. The authors also have provided flowcharts that students can use for identifying specific tissues in the major organ systems. Branch points in these flowcharts pertain to decisions as to whether an organ has a lumen or what type of epithelium is present. In summary, Basic Concepts in Cell Biology and Histology: A Student's Survival Guide is filled with must-know, medically relevant information. It provides a helpful bridge between the basic science disciplines. Medical students will find this book a helpful resource (survival guide) for class study and USMLE review. The authors have succeeded, and I highly recommend this book.

\author{
Bruce A. Fenderson \\ Jefferson Medical College, Thomas Jefferson \\ University \\ Philadelphia, Pennsylvania
}

